\title{
Substitution of Anchovy Waste Flour for Fish Meal as Conventional Feed on Quail Performance (Coturnix- coturnix japonica)
}

\author{
Andhika Putra, Ismail Dahlan, and Andika Pratama \\ Animal Husbandry Study Program, Faculty of Sains and Technologi, Universitas Pembangunan Panca \\ Budi, Indonesia
}

\begin{abstract}
Quail (Coturnix coturnix japonica) is one of the leading poultry that has a pretty good role and prospect as an egg producer and as a meat producer. The most important factor in the maintenance of quail is feed, because $80 \%$ of the costs incurred by farmers for the purchase of feed. Attempts to rotate waste is to utilize anchovy Waste enough to be used as a substitution of fish meal in the manufacture of artificial feed quail. Anchovy waste in artificial feed is expected to reduce the use of fish meal in quail feed. From the results of proximate test that has been done the protein content of starch produced $44.43 \%$. The purpose of this research is to know the content of the fish waste flour as a feed conventional to the growth. The method used in this research is Randomized Complete Design (RAL) with 5 treatments and 4 replications. Parameters used were feed consumption, average weight gain and feed conversion. The results showed that the use of anchovy waste flour as conventional feed was very helpful in the consumption of rations, weight gain and feed conversion. The conclusion of this study is used of anchovy waste can replace fish flour as a protein source in laying quail rations.
\end{abstract}

Keywords: anchovy waste flour, conventional feeding, quail

Received 26 July 2018 | Revised 9 August 2018 | Accepted 16 August 2018

\section{Introduction}

Quail (Coturnix coturnix japonica) is one of the poultry commodities that have the role and prospect is quite bright as an egg producer. Quail also provides the benefits of meat as one of the alternatives that support the availability of animal protein cheaply and easily obtainable, in addition to feathers and even quail poop can be utilized.

The most important factor in the maintenance of quail is the feed, because $80 \%$ of the costs incurred by farmers are used for the purchase of feed. The necessary nutrients must be present in the diet, the lack of any of the nutrients needed will have a devastating effect [1] Growing

*Corresponding author at: Animal Husbandry Study Program, Faculty of Sains and Technologi, Universitas Pembangunan Panca Budi, Jl. Jend. Gatot Subroto KM 4,5, Medan, 20122, Indonesia

E-mail address: Andhikaputra@dosen.pancabudi.ac.id 
animals need energy for body maintenance, meeting their needs for mechanical energy activity for muscle motion, and synthesis of new tissues [2].

Judging from the quality and quantity, the waste of anchovy is potential to serve as substitution of fish meal in the manufacture of artificial feed of quail. The use of anchovy fish meal flour in artificial feed is expected to reduce the use of fish meal in quail feed. From the results of proximate test that has been done to obtain the protein content of anchovy fish starch head as much as $44.5 \%$.

Research on the utilization of anchovy waste has been carried out in research for the growth of tilapia, which, according to research that the addition of fish meal in the ration of Tilapia can increase the growth of Tilapia fish [3]. The use of anchovy waste on the growth of ducks in rations showed results that were not significantly different [4]. The use of fish canning waste flour can be used up to $14 \%$ in broiler rations [5].

Anchovy head waste can be used as one of the alternative raw materials in artificial feed, because the waste of anchovy flour is able to replace the protein in fish meal. So far, the anchovy is used as processed food which is only used as animal feed or discharged into the environment. The use of anchovy head flour in artificial feed formulation is expected to be a substitute for manufactured man-made feed which is useful for increasing quail growth. Based on the above, the researcher will investigate by utilizing anchovy fish waste flour as conventional feed against quail growth.

\section{Materials and Methods}

\subsection{Research Materials and Tools}

This research was conducted in Dusun XIV Emplasmen, Sei Semayang Village, Sunggal Subdistrict Deli Serdang Regency. This research was conducted in January 2017 until March 2017. The materials used in this research are 100 quail DOQ (Day Old Quail) with an average initial body weight of $8.98 \pm 2.3$, commercial feed, fish waste meal flour, milled corn, rice bran, soybean meal, coconut meal, fish meal, and top mix. The tool to be used is a 4-level model cage, each with a length of $60 \mathrm{~cm}$, a width of $40 \mathrm{~cm}$ and a height of $30 \mathrm{~cm}$, the enclosure consists of 20 feeding units, 20 units of drinking and a digital salter scale of $5000 \mathrm{~g}$ capacity to weigh quail weight and also to weigh the ration, the thermometer is also used as a tool to measure the temperature of the cage, and other tools such as brooms, buckets and shovels.

\subsection{Research Methods}

The method used in this research is completely randomized design (CRD) with 5 treatments and 4 replications. The treatment provided is as follows:

$\mathrm{T} 0=$ Commercial feed (control) 
$\mathrm{T} 1=$ Conventional feed with $10 \%$ fish meal without fish meal waste flour

$\mathrm{T} 2=$ Conventional feed with $7 \%$ fish meal $+3 \%$ fish meal waste flour

$\mathrm{T} 3=$ Conventional feed with $3 \%$ fish meal $+7 \%$ fish meal waste flour

$\mathrm{T} 4=$ Conventional feed with $10 \%$ fish starch flour without fish meal

The collection of consumption data by means of feed is given in accordance with the treatment with giving every morning and evening. Feed is weighed and recorded before being given and the remaining feed that is still in the feed is weighed and recorded. Feed consumption is calculated by means of the feed given minus the remaining food every day (gram / head / day) and feed conversion is the quail ability to convert feed into eggs calculated every week during the study.

Table 1. Formulation Ration of Research

\begin{tabular}{lrrrrr}
\hline \multirow{2}{*}{ Feed Ingredient } & \multicolumn{5}{c}{ Treatment $\%$} \\
\cline { 2 - 6 } & \multicolumn{1}{c}{ T0 } & \multicolumn{1}{c}{ T2 } & \multicolumn{1}{c}{ T3 } & \multicolumn{1}{c}{ T4 } \\
\hline Commercial feed & 100 & 0 & 0 & 0 & 0 \\
Milled corn & 0 & 45 & 45 & 45 & 45 \\
Rice bran & 0 & 20 & 20 & 20 & 20 \\
Soybean meal & 0 & 13 & 13 & 13 & 13 \\
Coconut cake & 0 & 10 & 10 & 10 & 10 \\
Fish Flour & 0 & 10 & 7 & 3 & 0 \\
Anchovy waste flour & 0 & 0 & 3 & 7 & 10 \\
Mineral & 0 & 2 & 2 & 2 & 2 \\
\hline \multicolumn{1}{c}{ Amount } & 100 & 100 & 100 & 100 & 100 \\
\hline
\end{tabular}

\subsection{Data Analysis}

The linear model used in this research is completely randomized design (CRD) with linear model as follows:

$$
\text { Yij: } \mu+\mathrm{i}+\Sigma \mathrm{ij}
$$

Note:

Yij : The results of observation of the $\mathrm{i}$-th treatment and the $\mathrm{j}$-th repetition

M : General mean value

i : The effect of i-th treatment

$\Sigma \mathrm{ij}:$ Experimental error due to the thirteenth and $\mathrm{j}$ th test

If there is a real difference, it will be tested further using advanced test that is adjusted to the coefficient of data diversity of research results 


\subsection{Research Implementation}

a. Cage Preparation

The enclosure used is a colony enclosure made of wood and a $0.6 \times 0,4 \times 0.3 \mathrm{~m}$ ram wire arranged into 4 levels with the number of 5 cages at each level. In each cage is placed the tool heater in the form of incandescent lamp 60 Watt until quail aged 14 days.

\section{b. Livestock Preparation}

The study used 100 quail bought from farms quail. Newly introduced quails are given sugar water to replace energy the lost quail. The day after the quail came, weighing weights body to know the body weight of early quail.

\section{c. Research Treatment and Data Retrieval}

The preliminary stage begins with the preparation of basal rations, making ration with fish meal waste flour and also fish meal as well a combination of the two. Giving rations are given on adlibitum.

Weighing the rest of the ration to know the consumption of quail and done once a day in the morning. Weighing the weight done once a week to know the body weight from the beginning to the end of the week. FCR (Feed Conversion Ratio) or feed conversion is calculated a week once done by calculating the weight of the body distributed with consumption from start to end of week.

\subsection{Observed Variables}

a. Consumption of Rations (g)

Ration consumption data obtained by weighing rations given for a day, then reduced by weighing the rest of the ration for one day. Consumption Rations = Initial Ration - Final ration (gram).

b. Increase of Body Weight ( $\mathrm{g}$ )

The weight gain data is obtained by each weighing week which is the difference between weighing the final body weight with weighing the initial weight of unity of time (grams / weeks). The weight gain body $=$ weight of final weight - initial weight.

\section{c. Convert Rations}

The ration conversion data is calculated every week by the way comparing the amount of ration (grams) consumed by increasing body weight (grams) every week. Convert Rations = Consumption of Rations (g) / Increase of Body Weight (g). 


\section{Results and Discussion}

The results of the research in Table 1 shows that the use of fish starch head flour to quail performance gives significantly different results $\mathrm{P}>0.05$. the results showed that the provision of fish meal in the preparation of quail ration much as $10 \%$ in the ration gave the same results with the provision of $10 \%$ starch of starch in the rations in ration consumption, but gave different results in terms of weight gain and ration conversion. Where the best weight gain and best ration conversion by using anchovy head flour.

Table 2. Average Recapitulation of Research Result

\begin{tabular}{|c|c|c|c|}
\hline \multirow[b]{2}{*}{ Treatment } & \multicolumn{3}{|c|}{ Parameters } \\
\hline & $\begin{array}{l}\text { Average Consumption of } \\
\text { Rations } \mathrm{g} / \text { head/day }\end{array}$ & $\begin{array}{l}\text { Average Increase of Body } \\
\text { Weight } \mathrm{g} / \text { head/day }\end{array}$ & $\begin{array}{l}\text { Convert } \\
\text { Rations }\end{array}$ \\
\hline T0 & $124.52^{\mathrm{a}}$ & $21.66^{\mathrm{a}}$ & $5.75^{\mathrm{c}}$ \\
\hline $\mathrm{T} 1$ & $117.79 b$ & $17.81 \mathrm{c}$ & $6.63 b$ \\
\hline $\mathrm{T} 2$ & $113.69 \mathrm{c}$ & $15.15 d$ & $7.53 \mathrm{a}$ \\
\hline T3 & $117.41 \mathrm{~b}$ & $15.42 \mathrm{~d}$ & $7.62 \mathrm{a}$ \\
\hline T4 & $122.02 \mathrm{a}$ & $19.15 b$ & $6.39 b$ \\
\hline
\end{tabular}

Notes: different notations show significantly different

\subsection{Consumption of Rations (g)}

The higher consumption on this research showed that on $\mathrm{T} 0$ (commercial feed) because it has been tested favored by quail, in addition to having good nutritional value, commercial feed also has a standardized feed in producing high-quality feed. [6] Combination of ingredients contained in the feed adjusted for age quail. Standardization of feed for quail is divided into two types based on the National Standardization Agency, namely quail layer laying quail and quail laying quail feed. [7] also stated that feed into factory production (commercial feed) is already industry scale. By relying on the production machines are quite sophisticated, standardization of feed ingredients can be done and nutrient levels of animal feed produced quality maintained.

The results also showed the highest conventional feed intake of rations consumed in T4 treatment (conventional feed with $10 \%$ fish waste flour without fish meal). Parallel to [8]. Utilization of fish waste as feed based on two things, namely the number and quality. Fish waste flour contains fairly high protein.

Ration consumption is influenced by the energy level of the ration, the balance of nutrients, the temperature of the environment, the physical form of ration, body weight or body size, growth rate, and production [9]. According to [10], the special nature of poultry in consuming rations firstly to meet energy needs so that the rations eaten each day tend to be associated with energy levels. The results of the study [11], stated that male quails aged 0-7 weeks on average consumed rations of 547.75 grams per head with a body weight gain of 118.78 grams. 


\subsection{Body Weight Gain (g)}

The effect of giving shrimp meal as fish meal substitution to body weight gain showed the highest average result achieved by T0 treatment (commercial feed / manufacturer), very different to $\mathrm{T} 1$ treatment (Conventional Feed with $10 \%$ fish meal without fish meal flour) to $\mathrm{T} 2$ treatment (conventional feed with $7 \%$ Fish meal $+3 \%$ fish meal flour) to T3 treatment (conventional feed with 3\% Fish meal $+7 \%$ fish meal flour) and T4 treatment (Conventional feed with $10 \%$ flour fish waste without fish meal) [12].

This is because body weight is an accumulation of metabolic results. The metabolic outcome is supported by the amount of feed consumed and optimized the use of feed. Poultry requires a sufficient nutritional intake to increase body weight during growth. One of them by increasing the consumption of feed. This is also in line with [11] states that the weight of the livestock body is always directly proportional to the consumption of rations, the higher the body weight, the higher the consumption of rations.

Higher protein content will result in higher body weight growth as well. According to [12] that the quality and quantity of protein is important in the maintenance of poultry. Protein content will affect the growth rate. This study is in line with [13] that the content of protein and amino acids are balanced will increase body weight growth. According to [14] which states unlike other poultry animals, quail is a livestock that is very sensitive to changes in feed. Sudden changes in feed can reduce appetite, which may result in lower production rates. We recommend that the period of change of feed done gradually. During the turn period, quail should be given anti-stress mixed in drinking water.

\subsection{Convert Rations}

The effect of shrimp flour as a substitution of fish meal on ration conversion showed the lowest average yield was in T0 treatment (commercial feed / manufacturer), very different from $\mathrm{T} 1$ treatment (Conventional Feed with 10\% fish meal without fish meal flour) T2 (Conventional Feed with 7\% Fish Powder $+3 \%$ fish meal waste), and T3 (conventional feed with 3\% fish meal $+7 \%$ fish meal flour) but not significantly different from T4 treatment (conventional feed with $10 \%$ fish waste flour without fish meal). This is because the conversion of rations describes the efficiency of ration use which is a reflection of the relationship between growth and consumption of rations. The ability of livestock in utilizing rations to increase body weight will decrease with age. The ability of livestock in utilizing the ration and the effectiveness or absence of ration given can be known the result of the conversion value of the ration obtained [15].

According to [14] that the factors that influence the conversion of rations in quail are genetic improvements to obtain high body weight with low consumption, which in turn is found to use a 
more efficient ration or low ration conversion. The lower the conversion rate of the ration, the more efficient in the use of rations [15]. Quail ration conversion value for seven weeks is 4.89 [16].

\section{Conclusion and Recommendation}

Fish starch flour can be used as substitution of fish meal in the preparation of quail ration with maximum amount of $10 \%$ in the preparation of ration in accordance with the results of research conducted. The use of anchovy head flour is highly recommended for quail farmers to reduce the waste of anchovy and reduce production costs of quail farms.

\section{REFERENCES}

[1] E. Listiyowati, Tatalaksana Budidaya Puyuh Secara Komersial. Edisi Revisi. Jakarta: Penebar Swadaya, 2005.

[2] A. D. Tillman, Ilmu Makanan Ternak Dasar. Yogyakarta: Gadjah Mada University Press, 1998.

[3] M. Ali, L. Santosa, and D. Fransiska, "Pengaruh substitusi tepung ikan dengan tepung kepala ikan teri terhadap pertumbuhan ikan nila (Oreochromis Sp.)," Maspari Journal, vol. 7, no. 1, pp.63-70, 2015.

[4] Nurmeiliasari, Kususiyah, and E. Afriansyah, "Performance pertumbuhan itik talang benih jantan melalui pemanfaatan limba ikan teri sebagai sumber protein ransum," Jurnal Sains Peternakan Indonesia, vol.5, no.2, 2010.

[5] A. Baye, F. N. Sompie, B. Bagau, and M. Regar, "Penggunaan tepung limbah pengalengan ikan dalam ransum terhadap performa broiler," Jurnal Zootek, vol. 35, no. 1, 2015.

[6] T. Hartono, Permasalahan Puyuh dan Solusinya. Jakarta: Penebar Swadaya, 2004.

[7] Z. Abidin, Meningkatkan Produktifitas Puyuh (Si Kecil yang Penuh Potensi). Jakarta: Agro Media Pustaka, 2002.

[8] A. Parakkasi, Ilmu Nutrisi dan Makanan Ternak Ruminan. Bandung: Angkasa, 1983.

[9] NRC (National Research Council). Nutrient Requirement of Poultry. USA. 1997.

[10] A. D. Tillman, Komposisi Bahan Makanan Ternak Untuk Indonesia. Yogyakarta: Gadjah Mada University Press, 1991.

[11] H. R. Kartadisastra, Penyediaan dan Pengelolaan Pakan Ternak Ruminansia. Yogyakarta: Kanisus, 1997.

[12] F. B. Morrison, Feed and Feeding. USA, Iowa: The Morrison Publishing Co. Clinton, 1967.

[13] L. A. Maynard; J. K. Loosli; H. F. Hintz; and R. G. Warner, Animal Nutrition. New Delhi: Bombay, Mc Graw-Hill Publishing Press, 1979.

[14] M. C. Nesheim, R. E. Austic, L. E. Card, Poultry Production. Philadelphia: Lea \& Febiger, 1976.

[15] M. Rasyaf, Beternak Ayam Pedaging. Jakarta: Penebar Swadaya, 1993.

[16] R. R. Dewi, E. Sujana, and A. Anang, "Performa pertumbuhan puyuh (Coturnix-Coturnix Japonica) petelur jantan hasil persilangan warna bulu hitam dan coklat umur 0-7 minggu di Pusat Pembibitan Puyuh Universitas Padjadjaran,” Student E journal, vol. 5, no. 4, 2016. 